JURNAL PENDIDIKAN, p-ISSN 2715-095X, e-ISSN 2686-5041

Volume 29, No.3, Nopember 2020 (269-278)

Online: http://journal.univetbantara.ac.id/index.php/jp

\title{
Upaya Meningkatkan Prestasi Belajar IPS Melalui Metode Pembelajaran Kooperatif Tipe STAD Pada Siswa Kelas IX A SMP Negeri 2 Sukoharjo Semester I Tahun Pelajaran 2019/2020
}

\author{
Sri Wahyuni
}

Guru SMP Negeri 2 Sukoharjo, Email: Yyuni48@gmail.com

\begin{abstract}
Abstrak: Tujuan penelitian tindakan kelas ini adalah untuk meningkatkan prestasi belajar IPS melalui metode pembelajaran kooperatif tipe STAD pada siswa kelas IX A semester I SMP Negeri 2 Sukoharjo tahun pelajaran 2019/2020.Penelitian ini dilaksanakan pada bulan Juli sampai November 2019 di SMP Negeri 2 Sukoharjo. Subjek penelitian ini adalah siswa kelas IX A sebanyak 32 siswa. Penelitian Tindakan Kelas ini dilakukan dalam dua siklus. Teknik pengumpulan data menggunakan teknik dokumentasi, observasi, dan tes tertulis. Alat pengumpulan data berupa lembar pengamatan, butir soal tes, dan dokumen daftar nilai. Analisis data menggunakan analisis deskriptif komparatif yang dilanjutkan refleksi. Setiap siklus terdiri dari empat langkah, yaitu: (1) Perencanaan, (2) Pelaksanaan Tindakan, (3) pengamatan, dan (4) Refleksi. Hasil penelitian menunjukkan adanya peningkatan prestasi belajar IPS siswa, nilai rata-rata prestasi belajar IPS siswa mengalami peningkatan yaitu sebelum tindakan sebesar 68,8 , pada siklus I sebesar 77,4 dan pada siklus II sebesar 85,4. Selain itu, persentase ketuntasan belajar siswa juga meningkat, yaitu sebelum tindakan sebesar $53,1 \%$, siklus I sebesar $71,9 \%$ dan siklus II sebesar $93,8 \%$. Sehingga dapat disimpulkan bahwa "Metodepembelajaran kooperatif tipe STAD dapat meningkatkan prestasi belajar IPS siswa kelas IX A semester I SMP Negeri 2 Sukoharjo tahun pelajaran 2019/2020".
\end{abstract}

Kata-kata Kunci: Prestasi Belajar IPS, Metode Pembelajaran kooperatif tipe STAD

\section{Efforts to Improve The Achievement of IPS Learning Through STAD Type Cooperative Learning Methods in Class IX A Students of SMP Negeri 2 Sukoharjo Semester I Study Year 2019/2020}

\author{
Sri Wahyuni
}

The Teacher of SMP Negeri 2 Sukoharjo,Email: Yyuni48@gmail.com

\begin{abstract}
The purpose of this classroom action research is to improve social studies learning achievement through the STAD type cooperative learning method in class IX A students in the first semester of SMP Negeri 2 Sukoharjo in the academic year 2019/2020. This research was conducted from July to November 2019 at SMP Negeri 2 Sukoharjo. Subjects This research consisted of 32 students of class IX A. This Classroom Action Research was conducted in two cycles. Data collection techniques used documentation, observation, and written tests. Data collection tools were in the form of observation sheets, test items, and a list of scores. Data analysis used comparative descriptive analysis followed by reflection. Each cycle consists of four steps, namely: (1) Planning, (2) Implementing Actions, (3) observing, and (4) Reflecting. The results showed that there was an increase in students' social studies learning achievement, the average value of student social studies learning achievement had increased, namely before the action was 68.8, in cycle I was 77.4 and in cycle II was 85.4. In addition, the percentage of student learning completeness also increased, namely before the action was $53.1 \%$, cycle I was $71.9 \%$ and cycle II was $93.8 \%$. So it can be concluded that "the STAD type
\end{abstract}


of cooperative learning method can improve the social studies achievement of class IX A students in the first semester of SMP Negeri 2 Sukoharjo in the 2019/2020 school year".

Keywords: Social Studies Learning Achievement, Cooperative Learning Method type STAD

\section{Pendahuluan}

Penyelenggaraan Pendidikan merupakan tanggung jawab bersama antara pemerintah, masyarakat dan keluarga. Masing-masing memiliki peran yang sangat besar dalam rangka mewujudkan tujuan Pendidikan. Keberhasilan penyelenggaraan Pendidikan merupakan keberhasilan bersama. Tidak bisa salah satu pihak menyatakan dirinya sebagai yang paling berhasil dalam penyelenggaraan Pendidikan. Belajar IPS akan menyenangkan kalau memahami keindahannya, mengetahui manfaatnya, atau merasa tertantang oleh fenomena alam, kehidupan sosial dan perubahan masyarakat global yang belum siswa fahami. Jika siswa sudah mulai tertarik baik oleh keindahannya, manfaatnya atau merasa tertantang untuk memahami fenomena di atas yang mereka hadapi maka mereka akan bisa lebih mudah dalam menguasai pelajaran IPS. Oleh karena itu, motivasi belajar merupakan modal pertama untuk menghadapi halangan atau kesulitan apapun ketika sedang belajar. Kesadaran orang tua, dan masyarakat dalam mendukung pelaksanaan kegiatan Pendidikan sangat diperlukan. Setiap orang tua harus mampu memberikan motivasi yang besar kepada anak-anaknya untuk mengikuti kegiatan pembelajaran di sekolah. Sedangkan warga masyarakat juga harus dapat menciptakan kondisi lingkungan yang kondusif sehingga setiap anak selalu berusaha untuk dapat melakukan kegiatan belajar dengan aman dan nyaman. Pelajaran IPS diberikan kepada jenjang pendidikan SMPpada kurikulum 2013.Banyak guru yang menyadari bahwa IPS dianggap sebagai pelajaran yang membosankan oleh sebagian besar siswa. Sehingga banyak siswa yang mengeluh tentang kesulitan belajar dalam mengikuti pembelajaran IPS. Dari hasil pengamatan, nilai rata-rata ulangan harian siswa dalam belajar IPS masih rendah yaitu belum mencapai KKM. Hal ini dibuktikan dengan nilai yang didapat siswa kelas IX A SMP Negeri 2 Sukoharjomasih banyak siswa mendapat nilai dibawah $70(\mathrm{KKM})$. Kesulitan ini sering kita jumpai pada saat proses KBM berlangsung, rendahnya prestasi belajar siswa karena kurangnya semangat belajar siswa. Dalam satu kelas hanya terdapat beberapa siswa yang merespon, menyerap dan bahkan mengerjakan soal - soal latihan. Salah satu penyebabnya adalah cara penyajian belajar dan suasana pembelajaran yang kurang menarik dan menyenangkan. Guru kurang kreatif dan inovatif dalam menyampaikan pelajaran, dimana guru masih menggunakan metode ceramah dan kurang melibatkan siswa sehingga siswa menjadi cepat bosan bahkan terkadang siswa hanya duduk, diam, dan tidak ada gagasan atau ide yang ingin diucapkan. Padahal sering kali dalam proses pembelajaran adanya kecenderungan siswa tidak bertanya pada guru meskipun sebenarnya siswa belum mengerti materi yang sedang diajarkan. Hal ini berakibat pada hasil belajar IPS siswa.

Berdasarkan hasil pengamatan peneliti selaku guru IPS kelas IX A SMP Negeri 2 Sukoharjo, masalah yang dihadapi oleh siswa sejauh ini adalah kurangnya keaktifan dan rendahnya prestasi belajar siswa, salah satunya adalah materi Letak dan luas Benua Asia dan Benua lainnya. Karena pada materi ini siswa diharapkan dapat mendiskripsikan dan 
menganalisis Letak dan luas Benua Asia dan Benua lainnya yang perlu ketelitian dan pemahaman geografi secara baik. Hal ini dapat dilihat dari kegiatan belajar mengajar di kelas IX A dengan KKM 70, nilai rata-rata hasil ulangan harian IPSmateri Letak dan luas Benua Asia dan Benua lainnya di kelas tersebut yaitu68,8 dengan persentase ketuntasan sebesar53,12\%. Selain itu, pada kegiatan pembelajaran di dalam kelas siswa hanya bersikap pasif, sedangkan yang aktif adalah guru. Sehingga siswa merasa bosan dan kurang termotivasi dalam belajar IPS. Untuk itu guru diharapkan dapat menciptakan suasana kelas yang menyenangkan sehingga siswa dapat termotivasi dalam belajar IPS dan dapat menambah keaktifan siswa dalam pembelajaran. Kurangnya suasana kelas yang menyenangkan dan perlu adanya suatu model pembelajaran yang inovatif dan kreatif yang dapat menumbuhkan semangat belajar IPS dan memperkuat daya ingat siswa terhadap materi yang dipelajari sehingga dapat menunjang terciptanya kegiatan belajar mengajar yang kondusif. Upaya untuk meningkatkan prestasi belajar IPS siswaadalah dengan menggunakan metode pembelajaran yang menarik minat belajar siswa. Untuk itu peneliti menerapkaan metode pembelajaran kooperatif tipe STAD yaitu model pembelajaran yang dapat memberikan kesempatan kepada siswa untuk mengguanakan ketrampilan bertanya dan membahas suatu masalah. Siswa dapat dengan intensif mengadakan penyelidikan mengenai suatu masalah, Siswa dapat mengembangkan bakat kepemimpinan dan mengajarkan berdiskusi. Guru dapat lebih memperhatikan siswa sebagai individu dan kebutuhan belajarnya. Dengan metode pembelajaran kooperatif tipe STADdiharapkan dapat melatih kerja sama dalam menyelesaikan masalah dengan pembentukan kelompok, pembelajarannya menarik, dan mendorong siswa untuk terjun kedalamnya, tidak monoton dan bersemangat dalam belajar karena suasana pembelajaran berlangsung menyenangkan, masing-masing kelompok dapat memperoleh point dan penghargaan sehingga mampu membantu siswa dalam meraih nilai yang tinggi. STAD (Student Teams Achievement Division) Pembagian Pencapaian Tim Siswa) merupakan salah satu metode pembelajaran kooperatif yang paling sederhana, dan merupakan metode yang paling baik untuk permulaan bagi para guru yang baru menggunakan pendekatan kooperatif (dalam Slavin 2005: 143). Pembelajaran kooperatif tipe STAD ini merupakan salah satu tipe dari pembelajaran kooperatif dengan menggunakan kelompok-kelompok kecil dengan anggota tiap kelompok 4-5 orang siswa secara heterogen. Diawali dengan penyampaian tujuan pembelajaran, penyampaian materi, kegiatan kelompok, kuis dan penghargaan kelompok. Menurut Slavin juga menyatakan bahwa pada STAD siswa ditempatkan dalam tim belajar beranggotakan 4-5 orang yang merupakan campuran menurut tingkat prestasi, jenis kelamin dan suku. Guru menyajikan pelajaran, dan kemudian siswa bekerja dalam tim mereka memastikan bahwa seluruh anggota tim telah menguasai pelajaran tersebut. Kemudian, seluruh siswa diberikan tes tentang materi tersebut, pada saat tes ini mereka tidak diperbolehkan saling membantu.

Menurut Suprijono (2011:133-134), langkah-langkah pembelajaran kooperatif model STAD ini didasarkan pada langkah-langkah kooperatif yang terdiri atas 6 langkah atau fase sebagai berikut: (1) Membentuk kelompok yang anggotanaya 4 orang secara heterogen (campuran menurut prestasi, jenis kelamin, suku, dan lain-lain); (2) Guru menyajikan pelajaran; (3) Guru memberi tugas kepada kelompok untuk dikerjakan oleh anggota-anggota kelompok. Anggota yang sudah mengerti dapat menjelaskan pada anggota lainnya sampai anggota dalam kelompok itu mengerti; (4) Guru memberi kuis/pertanyaan kepada seluruh siswa; (5) Memberi evaluasi; dan (6) Kesimpulan. Hasil belajar merupakan 
perubahan perilaku yang diperoleh pembelajar setelah mengalami aktivitas belajar (Anni et al. 2005). Perolehan aspek-aspek perubahan perilku tersebut tergantung pada pada yang di pelajari oleh pembelajar. Hasil belajar yang dicapai oleh siswa di sekolah merupakan tujuan dari kegiatan belajarnya. Berkenaan dengan tujuan ini, Bloom dalam Anni et al. (2005) mengemukakan taksonomi yang mencakup tiga kawasan, yaitu kawasan kognitif, afektif, dan psikomotorik. Pembelajaran ranah kognitif berkaitan dengan hasil pengetahuan, kemampuan dan kemahiran intelektual. Ranah kognitif mencakup beberapa kategori yaitu: pengetahuan, pemahaman, penerapan, analisis, sintesis dan penilaian. Berdasarkan uraian di atas, dapat dirumuskan permasalahan sebagai berikut: "Apakah metode pembelajaran kooperatif tipe STADdapat meningkatkan prestasi belajar IPS siswa kelas IX A semester I SMP Negeri 2 Sukoharjo tahun pelajaran 2019/2020?”.Tujuan penelitian ini adalah untuk meningkatkan prestasi belajar IPS dengan menerapkan metode pembelajarankooperatif tipe STAD pada siswa kelas IX A semester I SMP Negeri 2 Sukoharjo tahun pelajaran 2019/2020. Prestasi belajar IPS dibatasi pada materi Letak dan luas Benua Asia dan Benua lainnya.

\section{Metode Penelitian}

Penelitian ini adalah Penelitian Tindakan Kelas (PTK). PTK merupakan suatu pencermatan terhadap kegiatan yang sengaja dimunculkan, dan terjadi dalam sebuah kelas (Arikunto, 2010: 130).Penelitian ini dilaksanakan di SMP Negeri 2 Sukoharjo.Tahap-tahap pelaksanaan kegiatan dilakukan selama kurang lebih enam bulan yaitu sejak bulan Juli sampai dengan Desember 2019.Peneliti sebagai guru SMP Negeri 2 Sukoharjo bertindak sebagai subjek yang melakukan tindakan kelas.Teman sejawat sesame guru mata pelajaran IPS sebagai observer.Kepala Sekolah bertindak sebagai subjek yang membantu dalam perencanaan dan pengumpulan data.Subjek yang menerima tindakan adalah siswa kelas IX A SMP Negeri 2 Sukoharjo semester Itahun pelajaran 2019/20120 sebanyak 32 siswa. Teknik pengumpulan data yang digunakan adalah: tes, observasi dan dokumentasi. Tes adalah serentetan pertanyaan atau latihan serta alat lain yang digunakan untuk mengukur keterampilan, pengetahuan inteligensi, kemampuan atau bakat yang dimiliki oleh individu dan kelompok (Arikunto, 2010 : 193). Tes digunakan adalah jenis tes hasil(achievement test) berupa kuis individu.Tes ini digunakan untuk mengukur pencapaian siswa setelah mempelajari materi. Hal ini dapat juga sebagai alat untuk mengetahui tingkat pemahaman siswa setelah mempelajari materi Letak dan luas Benua Asia dan Benua lainnya dengan menggunakan metode pembelajaran kooperatif tipe STAD.

Tes yang digunakan adalah tes uraian yang jawabannya berupa isian berbentuk isian singkat atau uraian (Suprijono, 2013:138). Observasi atau pengamatan dilakukan guna memperoleh data yang akurat, dengan menggunakan lembar observasi.Lembar observasi digunakan untuk memonitor dan mengevaluasi setiap tindakan agar kegiatan observasi tidak terlepas dari konteks permasalahan dan tujuan penelitian. Observasi yang digunakan adalah observasi sistematis, yaitu observasi yang dilakukan oleh pengamat dengan menggunakan pedoman sebagai instrumen pengamatan dan observasi non-sistematis yang dilakukan dengan tidak menggunakan instrumen pengamatan.Dokumentasi diperoleh dari hasil kuis siswa, lembar observasi, lembar wawancara, catatan lapangan, daftar siswa, dan 
foto-foto selama proses kegiatan belajar mengajar. Dokumentasi ini dimaksudkan adalah sebagai bukti-bukti konkret dari penelitian tindakan kelas tersebut. Instrumen yang digunakan dalam penelitian berupa tes, lembar observasi dan lembar dokumentasi. Tes berbentuk tes tertulis maupun lisan yang dilakukan dalam post test dan kuis individu. Tes ini digunakan untuk mengetahui sejauh mana peningkatan prestasi belajar dengan menggunakan metode pembelajaran kooperatif tipe STAD. Lembar Observasi, digunakan lembar observasi pelaksanaan metode pembelajaran kooperatif tipe STAD. Lembar dokumentasi bertujuan untuk mengetahui data siswa selama kegiatan penelitian berlangsung.Lembar dokumentasi ini berupa, foto-foto kegiatan pembelajaran, daftar hadir kegiatan pembelajaran, daftar hadir, daftar nilai dan sebagainya. Indikator keberhasilan kinerja dalam penelitian ini adalah: (1) siswa dianggap mencapai ketuntasan belajar apabila mencapai lebih dari atau sama dengan KKM (KKM 70); (2) pembelajaran dianggap berhasil apabila tingkat ketuntasan kelas mencapai lebih dari atau sama dengan 90\%; dan (3) pembelajaran dianggap berhasil apabila siswa secara klasikal rata-rata mencapai lebih dari atau sama dengan 80 .

\section{Hasil Penelitian}

Deskripsi data hasil penelitian yang telah dilakukan di kelas IX A SMP Negeri 2 Sukoharjo adalah sebagai berikut.Berdasarkan observasi awal di kelas IX A mata pelajaran IPS dengan materiLetak dan luas Benua Asia dan Benua Lainnya diperoleh data, dari 32 siswa yang mencapai nilai kriteria ketuntasan minimal (KKM) sebanyak 17 siswa $(53,1 \%)$, dengan nilai rata-rata kelas sebesar 68,8.Penelitian ini dilakukan dengan indikator kinerja nilai rata-rata tes siswa sekurang-kurangnya 80,0 dan banyak siswa dengan nilai di atas KKM yaitu $\geq 70,0$ mencapai $\geq 85 \%$. Berdasarkan pengalaman peneliti sebagai guru IPS kelas IX A, guru masih mendominasi kegiatan pembelajaran dan siswa cenderung tidak aktif.Salah satu solusi yang dikembangkan adalah penggunaan metode pembelajaran yang baru yaitu dengan metode pembelajaran kooperatif tipe STAD. Dengan penggunaan metode pembelajaran tersebut diharapkan akan menciptakan suasana belajar yang berbeda, bervariasi dan menyenangkan sehingga dapat menarikperhatian siswa, meningkatkan keaktifan siswa yang muara akhirnya meningkatkan prestasi belajar siswa. Tindakan kelas siklus I dilaksanakan pada hari Senin, 16September 2019dan Sabtu, 21 September 2019 di SMP Negeri 2Sukoharjo kelas IX A. Setelah langkah apersepsi dilanjutkan dengan penyampaian materi Letak dan luas Benua Asia dan Benua lainnyapada KD 4.1 memahami pengetahuan tentang Letak dan luas Benua Asia, Benua Eropa, Benua Afrika, Benua Australia, Benua Amerikadengan metode pembelajaran kooperatif tipe STAD. Berdasarkan hasil evaluasi pada siklus I menunjukkan adanya peningkatan prestasi belajar siswa. Prestasi belajar siswa sebanyak 23 siswa mencapai nilai KKM atau 71,9\%, rata-rata kelas naik menjadi 77,4. Berdasarkan pengamatan tersebut dapat diketahui bahwa proses pembelajaran pada siklus pertama belum berhasilmaksimaldan belum mencapai indikator kinerja yang diharapkan. Peningkatan hasil, jika dibandingkan hasil prasiklus yang mencapai KKM sebanyak 17 siswa atau 53,1\% setelas diberi tindakan penerapan siklus I, siswa yang mencapai KKM sebanyak 23siswa atau $71.9 \%$.

Tabel 1.Perkembangan Siswa yang Mencapai KKM Sebelum Tindakan ke Siklus I

\begin{tabular}{cccc}
\hline No & Prestasi Siswa & Prasiklus & Siklus I \\
\hline 1 & Rata-rata & 68,8 & 77,4 \\
\hline
\end{tabular}




2 Siswa mencapai KKM $\quad 17 \quad 23$

Dari tabel di atas dapat disimpulkan bahwa prestasi belajar IPS materi Letak dan luas Benua Asia dan Benua lainnya, padapelaksanaan tindakan siklus I mengalami peningkatan. Sebelum dilakukan tindakan atau prasiklus, rata-rata prestasi belajar siswa sebesar 68,8 dan siswa yang mencapai KKM sebanyak 17 siswa, setelah tindakan siklus I,rata-rata prestasi belajar siswa menjadi 77,4 dan siswa yang mencapai KKM sebanyak 23 siswa sehingga meningkat 6 siswa. Setelah dievaluasi bersama dari pelaksanaan tindakan pada siklus I yang digunakan sebagai bagian pertimbangan perencanaan pembelajaran siklus berikutnya, dengan perencanaan perbaikan untuk mengatasi kekurangan dan kesalahan yang dilakukan pada siklus I. Tindakan kelas siklus II dilaksanakan pada hari Senin, 23 September 2019 dan Sabtu, 28 September 2019 dengan materi Letak dan luas benua Asia dan Benua lainnya pada KD 4.1 menganalisis karakteritik Benua Asia dan Benua lainnya. Berdasarkan pembelajaran secara keseluruhan pada tindakan kelas siklus II menunjukan adanya peningkatan yang signifikan.Rata-rata nilai prestasi belajar siswa kelas IX A naik menjadi 85,44 dan sebanyak 30 siswa $(93,8 \%)$ mencapai nilai KKM.

Tabel 2. Perkembangan Prestasi Belajar Siswa dari Siklus I ke Siklus II

\begin{tabular}{clcc}
\hline No & Prestasi Siswa & Siklus I & Siklus II \\
\hline 1 & Rata-rata & 77,4 & 85,4 \\
\hline 2 & Siswa mencapai KKM & 23 & 30 \\
\hline
\end{tabular}

Dari tabel di atas dapat disimpulkan bahwa prestasi belajar IPS materi Letak dan luas Benua Asia dan Benua lainnya dengan menggunakan metode pembelajaran kooperatif tipe STAD, padapelaksanaan tindakan siklus II mengalami peningkatan. Pada tindakan siklus I, rata-rata prestasi belajar siswa sebesar 77,4 dan siswa yang mencapai KKM sebanyak 23 siswa, setelah tindakan siklus II,rata-rata prestasi belajar siswa menjadi 85,4 dan siswa yang mencapai KKM sebanyak 30 siswa sehingga meningkat 7 siswa.Berdasarkan hasil tersebut dapat diketahui bahwa proses pembelajaran sampai dengan pada siklus II berjalan dengan baik dan telah memenuhi indikator kinerja yang diharapkan.

Pada siklus I dan II dengan penerapan tindakan menggunakan metode pembelajaran kooperatif tipe STAD, siswa lebih antusias dengan perasaan senang dalam mengikuti kegiatan pembelajaran. Nilai rata-rata siswa sejak sebelum diadakan penelitian hingga setelah diadakan penenelitian sampai dengan siklus II, dapat dilihat pada tabel berikut:

Tabel 3.Perkembangan Prestasi Belajar Siswa Sebelum Tindakan,Siklus I dan Siklus II

\begin{tabular}{llrcc}
\hline No & Prestasi Siswa & Prasiklus & Siklus I & Siklus II \\
\hline 1. & Rata-rata & 68,8 & 77,4 & 85,4 \\
\hline 2. & Siswa mencapai KKM & 17 & 23 & 30 \\
\hline
\end{tabular}

Dari tabeldi atas dapat disimpulkan bahwa hasil belajar materi Letak dan luas Benua Asia dan Benua lainnya dengan menggunakan metode pembelajaran kooperatif tipe STAD, di setiap pelaksanaan tindakan, baik siklus I dan siklus II mengalami peningkatan, yaitu: siswa yang mencapai KKM sebelum dilakukan tindakan atau prasiklus 17 siswa, setelah tidakan siklus I sebanyak 23 siswa dan setelah tindakan siklus II sebanya 30 siswa, sehingga peningkatan kumulatif dari sebelum tindakan/prasiklus sampai dengan siklus II sebesar 13 siswa. 
Tabel 4.Perkembangan Persentase Siswa Mencapai KKM Sebelum Tindakan, Siklus I dan Siklus II

\begin{tabular}{ccccc}
\hline No & Prestasi Siswa & Prasiklus & Siklus I & Siklus II \\
\hline & $\begin{array}{l}\text { Persentase Siswa } \\
\text { Mencapai KKM }\end{array}$ & $53,1 \%$ & $71,9 \%$ & $93,8 \%$ \\
\hline
\end{tabular}

Dari tabel di atas dapat disimpulkan bahwa prestasi belajar IPS materi Letak dan luas Benua Asia dan Benua lainnya dengan menggunakan metode pembelajaran kooperatif tipe STAD, di setiap pelaksanaan tindakan mengalami peningkatan, yaitu:persentase siswa yang mencapai KKM sebelum dilakukan tindakan atau prasiklus 53,1\%, setelah tidakan siklus I sebanyak 71,9\% dan setelah tindakan siklus II sebanya 93,8\%.

Tabel 5. Perkembangan Nilai Rata-rata Kelas Sebelum Tindakan, Siklus I dan Siklus II

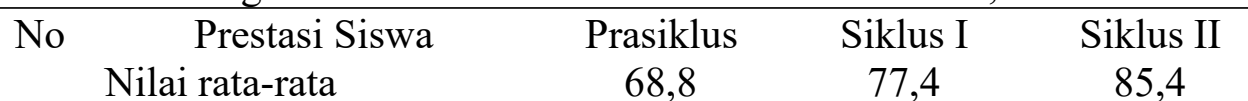

Dari tabel di atas dapat disimpulkan bahwa prestasi belajar materi Letak dan luas Benua Asia dan Benua lainnya dengan menggunakan metode pembelajaran kooperatif tipe STAD, di setiap pelaksanaan tindakan mengalami peningkatan, yaitu: nilai rata-rata kelas sebelum dilakukan tindakan atau prasiklus adalah 68,8, setelah tidakan siklus I adalah 77,4 dan setelah tindakan siklus II adalah 85,4 sehingga dari kondisi awal sebelum tindakan/prasiklus sampai dengan tidakan pada siklus II terjadi peningkatan.Dari uraian di atas dapat disimpulkan bahwa metode pembelajaran kooperatif tipe STADdapat meningkatkan prestasi belajarmateri Letak dan luas Benua Asia dan Benua lainnya siswa kelas IX A SMP Negeri 2 Sukoharjosemester Itahun pelajaran 2019/2020

\section{Pembahasan}

Pada penelitian kondisi awal diperoleh data yang dapat ditabulasikan sebagai berikut:

Tabel 6. Nilai Hasil Pengamatan awal

\begin{tabular}{cc}
\hline Nilai & Test Individual \\
\hline Terendah & 57 \\
\hline Tertinggi & 78 \\
\hline Jumlah & 2203 \\
\hline Rata-rata & 68.8 \\
\hline Persentase ketuntasan & $53.1 \%$ \\
\hline
\end{tabular}

Pada siklus I diperoleh data yang dapat ditabulasikan sebagai berikut:

Tabel 7. Nilai Hasil Pengamatan Siklus I

\begin{tabular}{cc}
\hline Nilai & Test Individual \\
\hline Terendah & 67 \\
\hline Tertinggi & 87 \\
\hline Jumlah & 2468 \\
\hline Rata-rata & 77.1 \\
\hline Persentase ketuntasan & $71.9 \%$
\end{tabular}

Pada siklus II diperoleh data yang dapat ditabulasikan seperti berikut: 
Tabel 8. Nilai Hasil Pengamatan Siklus II

\begin{tabular}{cc}
\hline Nilai & Test Individual \\
\hline Terendah & 69 \\
\hline Tertinggi & 95 \\
\hline Jumlah & 2734 \\
\hline Rata-rata & 85.4 \\
\hline Persentase ketuntasan & $93.8 \%$ \\
\hline
\end{tabular}

Tabel 9. Profil Kelas Sebelum dan Sesudah Tindakan Penelitian

\begin{tabular}{|c|c|c|c|c|c|}
\hline No & Hasil Siswa & & Kondisi Awal & Siklus I & Siklus II \\
\hline 2 & Nilai rata-rata & & 68,8 & 77,4 & 85,4 \\
\hline 3 & $\begin{array}{l}\text { Siswa yang } \\
\text { KKM }\end{array}$ & tiा & $\begin{array}{l}\text { 17siswa } \\
(53,1 \%)\end{array}$ & $\begin{array}{c}23 \text { siswa } \\
(71,9 \%)\end{array}$ & $\begin{array}{l}30 \text { siswa } \\
(93,8 \%)\end{array}$ \\
\hline
\end{tabular}

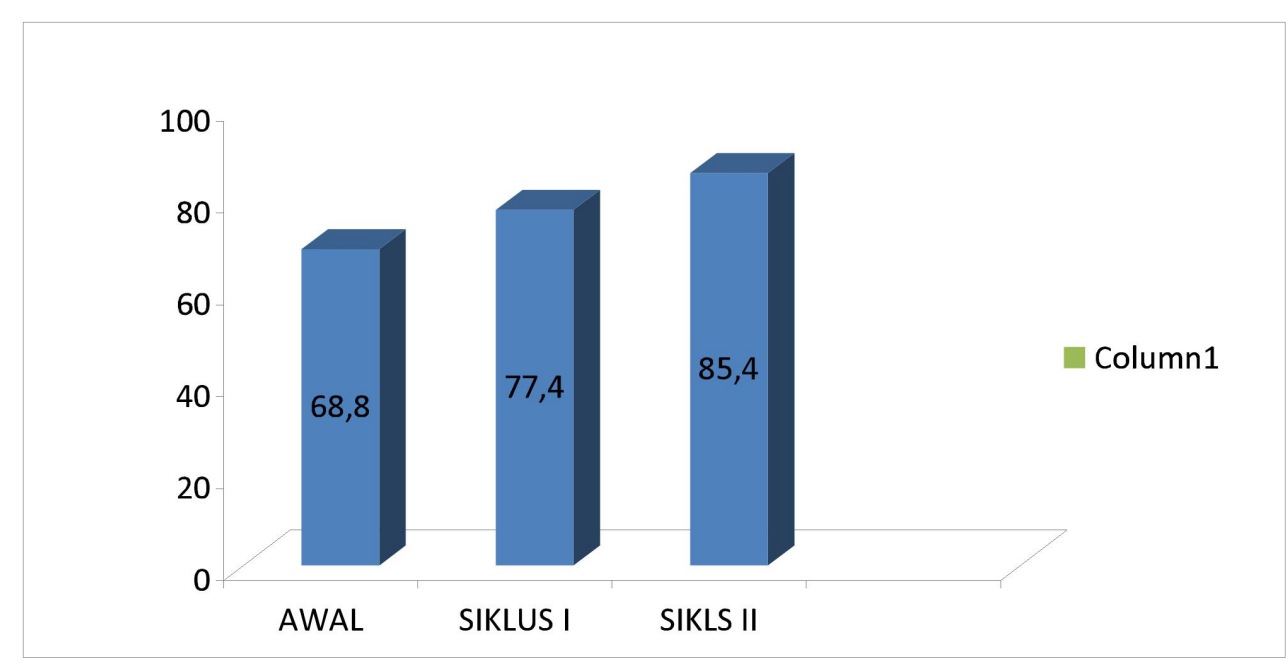

Gambar 1. Rata-rata Prestasi Belajar Siswa pada Kondisi Awal, Siklus I, dan Siklus II 


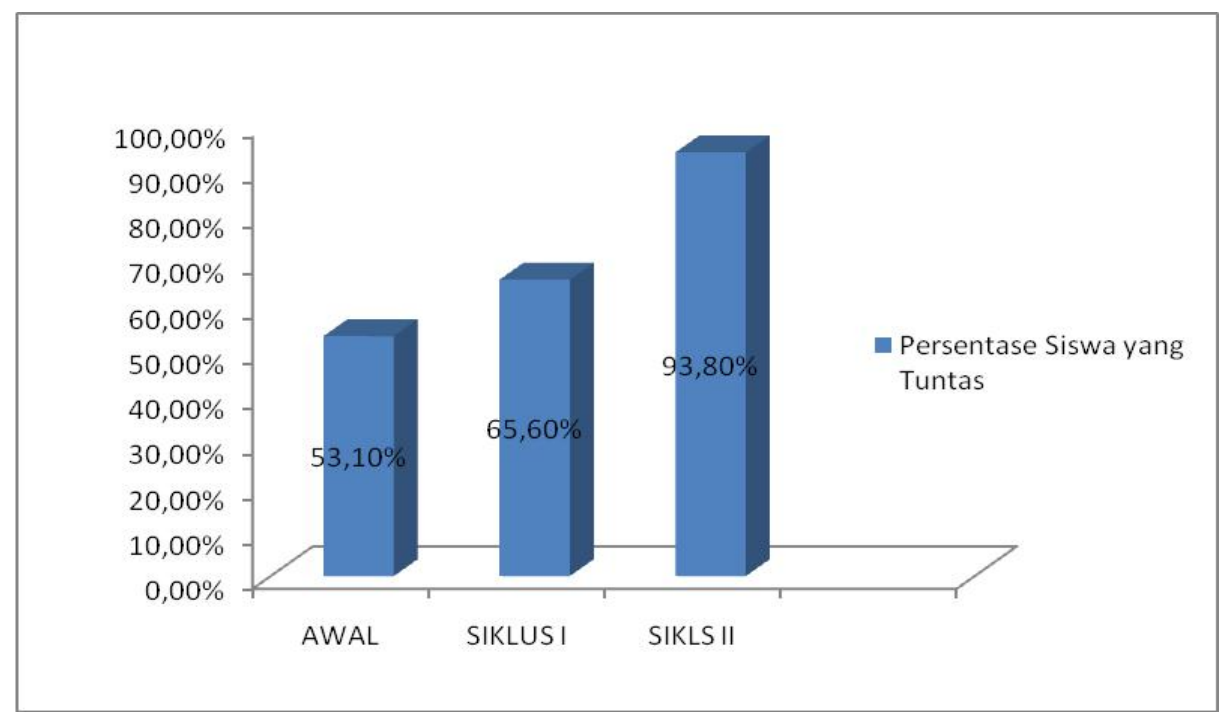

Gambar 2. Persentase Ketuntasan Siswa pada Kondisi Awal, Siklus I, dan Siklus II

Berdasarkan grafik di atas dapat ditunjukkan bahwa prestasi belajar siswa dengan menggunakan metode pembelajaran kooperatif tipe STAD di setiap putaran mengalami peningkatan, yaitu: (1) Sebelum dilakukan tindakan penelitian kelas nilai rata-rata hasil belajar siswa adalah 68,8 dengan presentase prestasi belajar siswa hanya $53,1 \%$, (2) Setelah dilakukan tindakan pada siklus I nilai rata-rata prestasi belajar siswa mengalami peningkatan yaitu 77,4 dengan presentase ketuntasan $71,9 \%$, tetapi belum mencapai indikator yang diharapkan; (3) Pada siklus II nilai rata-rataprestasi belajar siswa meningkat yaitu menjadi 85,4 dengan presentase ketuntasan sebesar 93,8\% dan sudah mencapai indikator yang diharapkan maka penelitian tindakan kelas ini sudah berhasil. Rata-rata prestasi belajar siswa pada kondisi awal 68,8 dengan persentase ketuntasan belajar siswa sebesar $53,1 \%$, pada siklus II naik menjadi $82,9 \geq 80,0$ (indikator kinerja) dengan presentase ketuntasan belajar siswa sebesar $93,8 \geq 85 \%$ (indikator kinerja). Jadi, indikator kinerja sudah tercapai sehingga tidak dilanjutkan ke siklus berikutnya.

\section{Simpulan dan Saran}

Berdasarkan hasil penelitian dapat disimpulkan bahwa: "Metode pembelajaran kooperatif tipe STAD dapat meningkatkan prestasi belajar IPS siswa kelas IX A semester I SMP Negeri 2 Sukoharjo tahun pelajaran 2019/2020. Hasil penelitian ini menunjukkan adanya peningkatan pada prestasi belajar IPS siswa. Hal ini dapat dilihat dari nilai rata-rata prestasi belajar IPS siswa juga mengalami peningkatan yaitu sebelum tindakan sebesar 68,8 , pada siklus I sebesar 77,4 dan pada siklus II sebesar 85,4. Selain itu, persentase ketuntasan belajar siswa, yaitu sebelum tindakan sebesar $53,1 \%$, pada siklus I sebesar $77,9 \%$ dan pada siklus II sebesar $93,8 \%$.

PTK yang dilaksanakan di SMP Negeri 2 Sukoharjo ini sudah berjalan dengan cukup baik dan hasil yang baik pula.Namun masih banyak hal yang perlu diperbaiki.Oleh karena itu, peneliti memberikan beberapa saran.Dalam mengikuti pembelajaran IPS disarankan siswa dapat aktif dalam beraktifitas dikelas baik saat kegiatan belajar mengajar 
(KBM) ataupun saat berdiskusi kelompok.Sehingga dapat meningkatkan pemahaman materi yang sedang diajarkan dan dapat meningkatkan prestasi belajar siswa yang optimal sehingga dapat mencapai melebihi KKM. Guru IPS hendaknya dapat menumbuh kembangkan kreativitas dalam menjalankan profesinya sebagai fasilitator dan motivator dalam menyampaikan pembelajaran secara kreaktif dan inovatif pada siswa dalam penyampaian materi, sehingga siswa dapat menerima dan memahami materi yang diajarkan dengan baik. Sekolah disarankan mengadakan rapat uintuk membahas metode pembelajaran yang inovatif dan menyenangkan seperti metode pembelajaran kooperatif tipe STAD untuk diterapkan dalam pembelajaran. Agar lebih meningkatkan keaktifan siswa dan prestasi belajar siswa dalam belajar bahasa IPS. PTK ini diharapkan akan membawa dampak positif terhadap perkembangan sekolah yang nampak pada peningkatan prestasi belajar siswa sehingga dapat meningkatkan prestasi dan kualitas sekolah.

\section{Daftar Rujukan}

Arikunto, Suharsimi. (2006). ProsedurPenelitian. Jakarta: RinekaCipta

SardimanA.M. (2010). Interaksi dan Motivasi Belajar Mengajar. Jakarta: PT Raja Grafindo Persada.

Sudiyana. (2012). Penelitian Tindakan Kelas. Yogyakarta: Cakra books dan Bradelvi.

Suprijono, Agus. (2013). Cooperative Learning Teori dan Aplikasinya. Yogyakarta: Pustaka Pelajar.

Warsono,Hariyanto.(2013). Pembelajaran Aktif Teori dan Assesmen. Bandung: PT Remaja Rosdakarya Offset. 